\title{
METAL AND METALLOID SEQUESTRATION IN A CONSTRUCTED WETLAND SYSTEM FOR TREATMENT OF LANDFILL LEACHATE DURING 2003-2012
}

\author{
Sylvia Waara \\ Tatsiana Bandaruk \\ Department of Environmental and Biosciences, School of Business \\ and Engineering, Halmstad University, Sweden
}

\begin{abstract}
The treatment of landfill leachate in constructed wetland systems is a common practice in Europe. However, very few studies were made to evaluate their performance over a long period of time. A free surface constructed wetland system consisting of sediment traps followed by 10 ponds connected with overflows was built at Atleverket near Örebro, Sweden in 2001. It receives pre-treated leachate from the municipal landfill. As part of the wetland monitoring programme a large data set on the surface concentrations of 15 metals and 2 metalloids has been collected from different sampling sites within the wetland during the operation period. In this study, the data from inlet and outlet of the wetland were compiled and analysed. The aim of this paper is therefore to estimate the removal efficiency of metals and metalloids using data on concentrations and flow and investigate the effect of wetland age on removal pattern. The elements with the highest removal efficiency were $\mathrm{Al}, \mathrm{As}, \mathrm{Ba}, \mathrm{Ca}$, $\mathrm{Cr}, \mathrm{Cu}, \mathrm{Fe}, \mathrm{Mn}, \mathrm{Pb}, \mathrm{V}$ and $\mathrm{Zn}$ ranging from $95 \%$ for $\mathrm{Pb}$ to $65 \%$ for $\mathrm{Ca}$. The elements with the lowest reduction were $\mathrm{B}$, Co K, Mg, $\mathrm{Ni}$ and S ranging from Co $56 \%$ to $40 \%$ for S. It was found that the removal efficiency was not related to inlet concentrations of the elements as the elements with high and low inlet concentrations were found in both groups. Analysis of reduction pattern also revealed that the group with higher removal efficiency showed fairly constant outlet concentrations during the study period, while the elements with lower removal efficiency demonstrated variable outlet concentrations. No statistical difference in removal due to age of the wetland was found. The study results showed that the wetland system has high removal efficiency of metals and metalloids and the removal pattern is not affected by age of the wetland. The influence on reduction due to leachate characteristics, wetland design and retention time will be discussed.
\end{abstract}

KEYWORDS

Landfill leachate, Treatment wetlands, Wetland design, Metals and metalloids. 


\section{INTRODUCTION}

Landfilling of municipal solid wastes is a common practice of waste management in many countries around the world[1]. Landfill leachates (LL) are produced due to different chemical and biochemical reactions occurring in the waste. These toxic liquids contain large amount of pollutants, some of which can be a threat to the health and environment if released into the nature without any treatment. Based on [1]-[3] all pollutants in the LL can be classified into four main groups: dissolved organic matter, inorganic macro-components, heavy metals, and xenobiotic organic compounds. Usually LLs have high concentrations of total dissolved solids, chemical oxygen demand (COD), biological oxygen demand (BOD) (with very low BOD/COD ratio), ammonia, phenols, chloride, iron, manganese, arsenic, heavy metals such as lead, cadmium, zinc or chromium but little or no phosphorus [4], [5]. Heavy metals and metalloids presented in the LL can cause negative environmental effect on soil, surface and ground water or even food chains.

There are many different treatment technologies available today for removal of the contaminants from the wastewaters. They are biological, chemical and physical [3], [6]. Finding an efficient treatment method is one of the main tasks for landfill management. Due to their reliability, simplicity and high cost-effectiveness, biological treatments are commonly used for this purpose. Constructed wetlands (CW) have been widely applied for treating different types of wastewaters, including sewage, storm waters, industrial wastewaters, agricultural runoff, acid mine drainage and LLs [7]. They are cost efficient alternatives to a conventional wastewater treatment plant. They can transform pollutants into harmless compounds or even nutrients and they are easy to operate and maintain. CWs are able to treat the wastewaters for decades. However, very few studies made to evaluate long-term performance of the CWs. Therefore, it is of interest to look at their functioning and pollutants removal over a long period of time.

There are different biological, chemical and physical processes included in metal removal in constructed wetlands. They are sedimentation, sorption, precipitation, plant uptake and others. The design of a wetland determines how wastewater will be treated and what mechanisms will be involved [8]-[10]. Wetlands in which the wastewater flows horizontally over the wetland sediment are called surface flow (SF) wetlands or free water surface (FWS) wetlands. Incoming wastewater enclosing many dissolved and particulate pollutants slows down its flow and dilutes with large area of shallow water with emerged and submerged vegetation [11], [12]. Usually these wetlands work as advanced system for pre-treated wastewaters in lagoons, trickling filters and activated sludge systems. FWS wetlands are suitable for all weather conditions including northern territories. FWS wetlands can deal with changing water level. Thus, they are the more favourable choice for leachate treatment than other wetland types. Operating costs are usually also low if compared to other CW types.

Presently, there are a limited number of studies published about the possibility of CWs to retain metals, metalloids from the LLs. Therefore, it is of great interest to study the behaviour of metals and metalloids and sulphur in the LLs treated in a constructed wetland over extended period of time. This study attempts to analyse the behaviour over the period of ten years along with estimation of removal efficiency. 


\section{MATERIALS AND METHODS}

Atleverket landfill is a municipal landfill which has been in operation since 1978. It receives all types of wastes (domestic waste, industrial waste, waste from the demolished buildings and sludge from sewage treatment plant) but no classified hazardous waste. Currently, 4ha out of 22ha of total landfill area are covered. Even though the wetland was not designed with the major aim of removing heavy metals and metalloids, and the target elements were nitrogen and organic materials, it has the potential to sequestrate these pollutants as has been shown previously [13], [14].

The Atleverket treatment wetland for landfill leachate in Örebro, Sweden was constructed in 2001. The wetland covers 8 ha. It consists of sediment traps followed by a series of ten ponds with surface flow connected with overflows. Before discharging leachate to the wetland, it is pre-treated in an aeration lagoon which also evens out the flow to the wetland system. Some parts of the pre-treated leachates go to the municipal sewage treatment plant (STP) while others are pumped into the wetland system. In 2005, three sludge/sediment traps were installed at the inlet. The sediment from ponds 1 and 2 were dredged up several times and kept in a dewatered pond. Landfill leachate, after being treated in the wetland, is discharged into a nearby river [13], [14].

The data measurements were taken every month and reveal a wide range of metals in LL. In this study the concentrations of metals and metalloids in the inlet and outlet and not within the wetland were taken for analysis. Two years have been excluded from the analysis as they did not have complete data about the flow. In addition, the values with a flow less than $250 \mathrm{~m}^{3} /$ month were not included in the analysis. Therefore, the data used in this work included metals and metalloids concentrations during ten years starting from 2003 to 2012 at two different sites, inlet and outlet. The data comprised the following metals: aluminium (Al), barium $(\mathrm{Ba})$, calcium $(\mathrm{Ca})$, cobalt $(\mathrm{Co})$, chromium $(\mathrm{Cr})$, copper $(\mathrm{Cu})$, iron $(\mathrm{Fe})$, potassium $(\mathrm{K})$, magnesium $(\mathrm{Mg})$, manganese $(\mathrm{Mn})$, nickel $(\mathrm{Ni})$, lead $(\mathrm{Pb})$, vanadium $(\mathrm{V})$ and zinc $(\mathrm{Zn})$, two metalloids: arsenic (As) and boron (B) and sulphur (S).

The following equation was used to calculate the load:

Load $=\frac{C_{i} * Q}{A}$

where:

$C_{i}$ - concentration of a chemical in the inlet $\left(\mathrm{g} / \mathrm{m}^{3}\right)$

$Q$ - flow in the inlet, $\mathrm{m}^{3} /$ year

$A$ - wetland area [15]

The statistical analysis of the data was conducted using STATISTICA 7 software package developed by StatSoft ${ }^{\circledR}$ Scandinavia AB, Uppsala, Sweden. Statistical significance between inlet and outlet metal and metalloid concentrations was assessed. Factorial analysis of variance (ANOVA) was selected as a valuable way for evaluating the influence of time on metal concentrations in two different sites, inlet and outlet. The significance level used for all tests was set at $\mathrm{p}<0.05$.

It was noted that two cases contained atypical values which did not fit the general trend. They contained six and four extreme values respectively. The first case was sampled in May 2007 


\section{Linnaeus ECO-TECH`14}

Kalmar, Sweden, November 24-26, 2014

and contained unlikely values for such elements like $\mathrm{Al}, \mathrm{As}, \mathrm{Ba}, \mathrm{Cu}, \mathrm{Fe}$ and $\mathrm{Zn}$. The second case was sampled in October 2011 and had extremely high values for Al, As, Fe and Pb. After more detailed analysis these two entire cases were excluded from the examination and they were defined as outliers.

As the wetland retention time is 6-12 months it was decided to analyse a possible change in concentrations with time and the removal efficiency by dividing the data into three time groups: early stage (2003-2005), mid stage (2006-2009) and late stage (2010-2012).

\section{RESULTS AND DISCUSSIONS}

Before applying the statistical test an assumption about the normality of the data was checked using the probability-probability plots. After excluding two cases with atypical concentrations mentioned above all points for each element fell onto the diagonal line proving the normality.

\subsection{General removal trend}

The removal efficiency over the whole period of ten years for each element was calculated for concentrations and mass. All concentrations are given in $\mathrm{mg} / \mathrm{l}$, mass is given in $\mathrm{kg}$ if other not stated. The results demonstrate that different elements have been retained with various efficiency rates. The lowest removal was indicated for Mg with 34\%. S, K, B and Ni had low removal rates as well with the numbers $40 \%, 41 \%, 42 \%$ and $45 \%$ respectively. The highest removal appeared to be for $\mathrm{Pb}$ (95\%). Fe (93\%), Vn (93\%), Zn (92\%), Mn (88\%) and $\mathrm{Al}$ (87\%) had also high efficient removal coefficient (see Table 1). It shouldalso should be noted that the influent concentration for all elements varies greatly. Using the total volume of water entering and going out of the wetland system the dilution was calculated for the whole period. It appeared to be $14 \%$.

Table 1 Metal, metalloid and sulphur removal for concentration and mass during 2003-2012

\begin{tabular}{|c|c|c|c|c|c|c|}
\hline \multirow{2}{*}{$\begin{array}{c}\text { Elemen } \\
\mathrm{t}\end{array}$} & \multicolumn{2}{|c|}{ Inlet $(n=48)$} & \multicolumn{2}{|c|}{ Outlet (n=144) } & \multicolumn{2}{|c|}{ Removal, \% } \\
\hline & Mean \pm SD, mg/l & Mass, kg & Mean \pm SD, mg/l & Mass, kg & For Conc. & For Mass \\
\hline Al & $1.377 \pm 0.814$ & 670.0 & $0.158 \pm 0.195$ & 87.8 & 89 & 87 \\
\hline As & $0.014 \pm 0.005$ & 6.7 & $0.002 \pm 0.001$ & 1.0 & 86 & 85 \\
\hline $\mathbf{B a}$ & $0.213 \pm 0.083$ & 103.8 & $0.031 \pm 0.017$ & 17.0 & 85 & 84 \\
\hline B & $1.724 \pm 0.411$ & 838.8 & $0.881 \pm 0.344$ & 490.6 & 49 & 42 \\
\hline $\mathrm{Ca}$ & $171.877 \pm 41.179$ & $83.7^{*}$ & $52.773 \pm 16.806$ & $29.4^{*}$ & 69 & 65 \\
\hline Co & $0.014 \pm 0.005$ & 7.0 & $0.006 \pm 0.004$ & 3.1 & 57 & 56 \\
\hline $\mathrm{Cr}$ & $0.049 \pm 0.024$ & 23.6 & $0.007 \pm 0.005$ & 3.9 & 86 & 83 \\
\hline $\mathbf{C u}$ & $0.033 \pm 0.014$ & 16.0 & $0.006 \pm 0.003$ & 3.7 & 82 & 77 \\
\hline $\mathbf{F e}$ & $8.963 \pm 4.549$ & $4.4^{*}$ & $0.518 \pm 0.579$ & 288.7 & 94 & 93 \\
\hline $\mathbf{K}$ & $222.357 \pm 66.243$ & $108.2^{*}$ & $113.960 \pm 47.927$ & $63.6^{2^{*}}$ & 49 & 41 \\
\hline Mg & $44.209 \pm 11.365$ & $21.5^{*}$ & $25.327 \pm 8.484$ & $14.1^{*}$ & 43 & 34 \\
\hline Mn & $2.271 \pm 0.798$ & $1.1^{*}$ & $0.236 \pm 0.303$ & 131.6 & 90 & 88 \\
\hline $\mathrm{Ni}$ & $0.043 \pm 0.011$ & 20.9 & $0.021 \pm 0.009$ & 11.5 & 51 & 45 \\
\hline $\mathbf{P b}$ & $0.008 \pm 0.004$ & 4.1 & $0.0004 \pm 0.00$ & 0.2 & 96 & 95 \\
\hline $\mathbf{S}$ & $43.730 \pm 11.380$ & $21.3^{*}$ & $22.717 \pm 8.642$ & $12.7^{*}$ & 48 & 40 \\
\hline $\mathbf{V}$ & $0.016 \pm 0.007$ & 7.6 & $0.001 \pm 0.001$ & 0.5 & 94 & 93 \\
\hline Zn & $0.199 \pm 0.089$ & 96.9 & $0.014 \pm 0.017$ & 7.7 & 93 & 92 \\
\hline \multicolumn{2}{|c|}{ Total inflow, $\mathrm{m}^{3} /$ year } & \multicolumn{5}{|c|}{$\mathbf{4 8 6 6 9 2}(43494275074808881235245755728329571517246869184095)$} \\
\hline \multicolumn{2}{|c|}{ Total outflow, $\mathrm{m}^{3} /$ year } & \multicolumn{5}{|c|}{557122 (59474 504455259668577363035987546175257073737102816$)$} \\
\hline \multicolumn{2}{|c|}{ Dilution, \% } & \multicolumn{5}{|c|}{14} \\
\hline
\end{tabular}

\footnotetext{
* - the concentrations are given in tons
} 


\section{Linnaeus ECO-TECH`14}

Kalmar, Sweden, November 24-26, 2014

Dilution could be a reason for pollutant depletion [16]. Thereby, it was quantitatively estimated over the whole period of time. The level appeared to be $14 \%$. It is a relatively low value which allows to conclude that the removal of the pollutants occur due to additional mechanisms within the wetland and not solely due to high dilution. In an earlier study of Atleverket CW during 2003-2006 the level of dilution was 15\% [13].

The outcome from statistical analysis has showed that the elements studied can be divided into two groups based upon outlet concentration. The first group (GROUP 1) had a pretty steady concentration line in the outlet no matter how different the concentration varied in the inlet. These elements were $\mathrm{Al}, \mathrm{As}, \mathrm{Ba}, \mathrm{Ca}, \mathrm{Cr}, \mathrm{Cu}, \mathrm{Fe}, \mathrm{Pb}, \mathrm{V}, \mathrm{Zn}$, and $\mathrm{Mn}$. Four elements are given as an example of such trend and presented in

Figure 1. As and $\mathrm{Cu}$ represent elements with low loading concentrations while $\mathrm{Ca}$ and $\mathrm{Fe}$ have high loading concentrations.

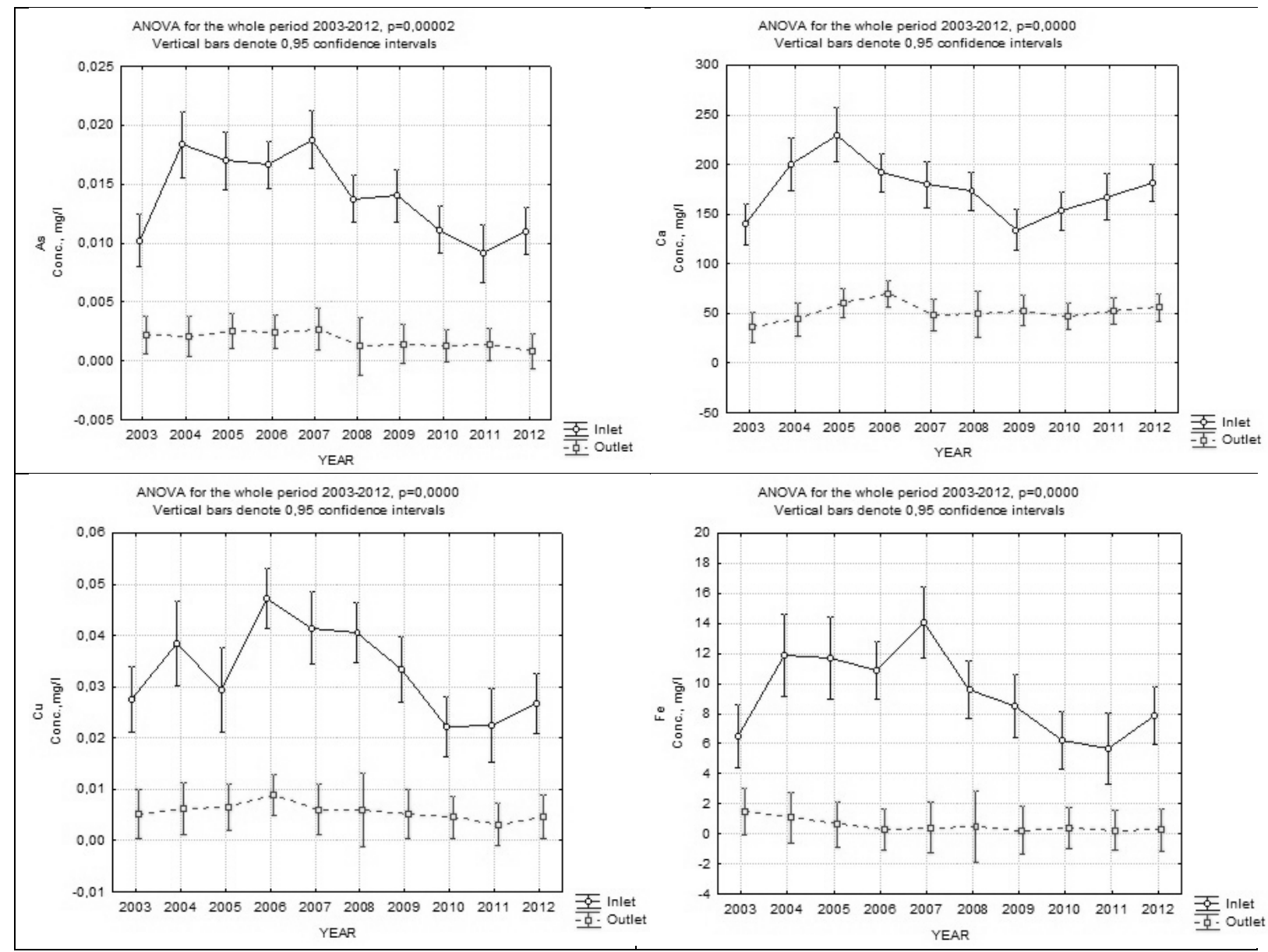

Figure 1 Inflow and outflow concentrations in CW during 2003-2012. GROUP 1

The second group (GROUP 2) also shows a reduction in the outlet concentration when compared to the concentrations in the inlet for all metals, metalloids and sulphur during the period under consideration. However, the average concentrations in the outlet have higher fluctuations when compared to GROUP 1 . The following elements belong to this group: $\mathrm{B}$, Co, K, Mg, S and Ni. 


\section{Linnaeus ECO-TECH 14}

Kalmar, Sweden, November 24-26, 2014

Figure 2 gives an overview how the overall trend occurs for GROUP 2 by the example of Co, $\mathrm{Ni}$ (low loading concentrations) and $\mathrm{Mg}$ and $\mathrm{K}$ (high loading concentrations).

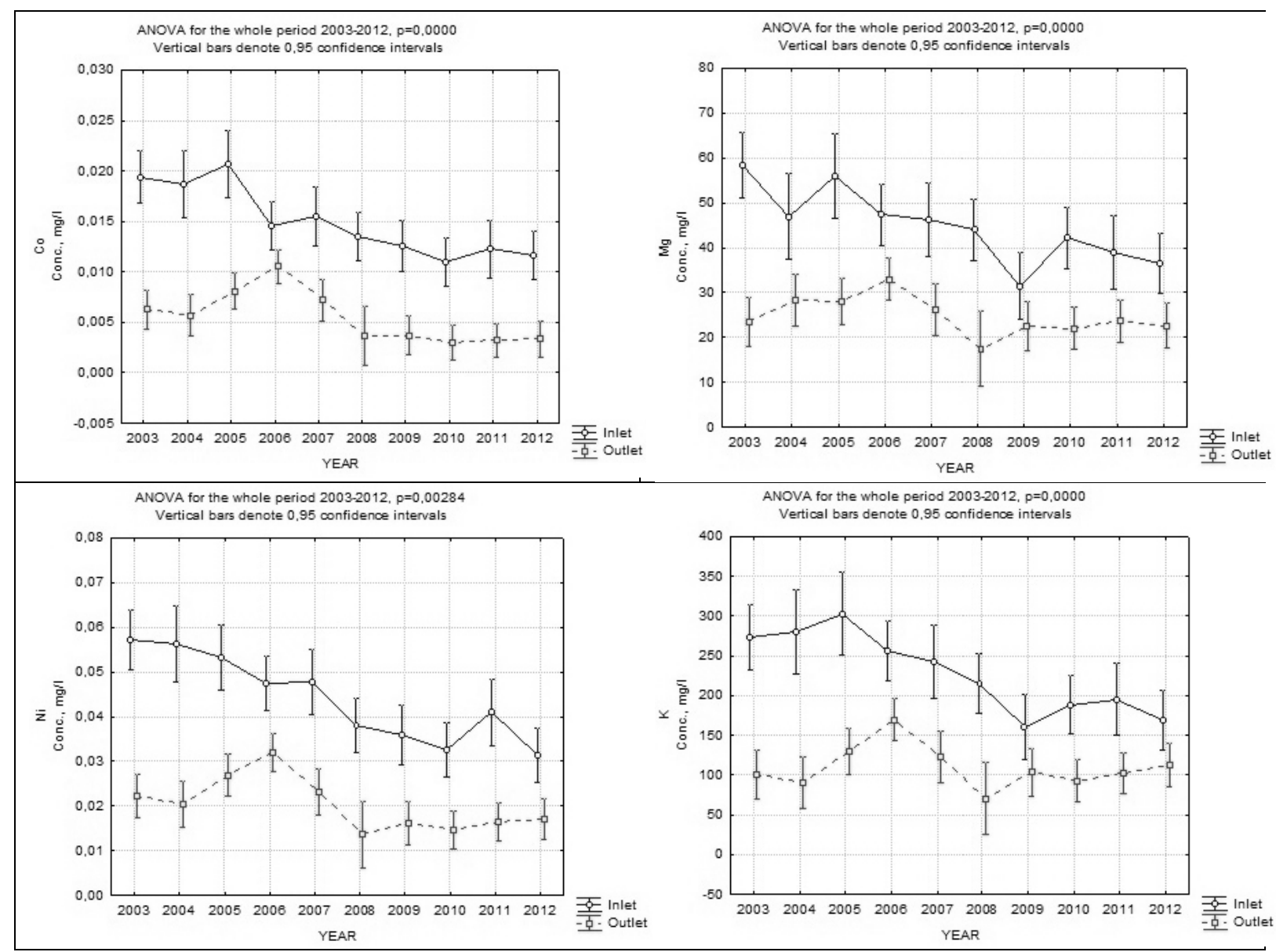

Figure 2 Inflow and outflow concentrations in CW during 2003-2012. GROUP 2

The effluent concentration removal efficiency remained fairly constant over the whole period for As, Al, Ba, V, Pb and Fe. This implies that $\mathrm{CW}$ tends to function approximately the same for removal these metals and metalloids. For $\mathrm{B}, \mathrm{Ca}, \mathrm{Cu}, \mathrm{Co}, \mathrm{Cr}, \mathrm{K}, \mathrm{Mg}, \mathrm{Ni}, \mathrm{S}$ and $\mathrm{Zn}$ concentration in the outlet was higher during 2006-2009 than the other years.

\subsection{The effect of the wetland age on the removal pattern}

The data were divided in to three time groups: early stage, mid and late stage accordingly. Early stage included the years 2003-2005, mid stage group 2006-2009 and the late stage group included all the four remaining years 2010-2012. The statistical analysis has shown a statistically significant reduction in concentration in all three groups for all elements.

Since 2006 (mid stage group) there was a statistically significant increase in the receiving concentration for such elements as $\mathrm{Al}, \mathrm{Pb}, \mathrm{Cu}, \mathrm{As}, \mathrm{Ba}, \mathrm{Zn}, \mathrm{S}, \mathrm{Mn}$ and Fe. For $\mathrm{Ca}$ and $\mathrm{V}$ the incoming concentration remained at almost the same level as in the early stage group. The mid stage group had a decrease in the incoming concentration for the following metals: $\mathrm{Co}, \mathrm{B}$, $\mathrm{Ni}, \mathrm{Mg}$ and $\mathrm{K}$. The late stage group can be characterised as decline in the incoming 


\section{Linnaeus ECO-TECH` 14}

Kalmar, Sweden, November 24-26, 2014

concentration for almost all elements but $\mathrm{S}$ when compared with the mid stage group. Sulphur unlike the others in its group (late stage) has shown a slight raise in concentration in the inlet. In spite of the variation in the input concentrations the wetland system managed to reduce the amount of contaminants to a certain level in all three age groups.

In figure 5 the above described trend is shown by the example of $\mathrm{Al}, \mathrm{K}, \mathrm{Fe}, \mathrm{Mg}, \mathrm{Co}$ and $\mathrm{Ni}$.

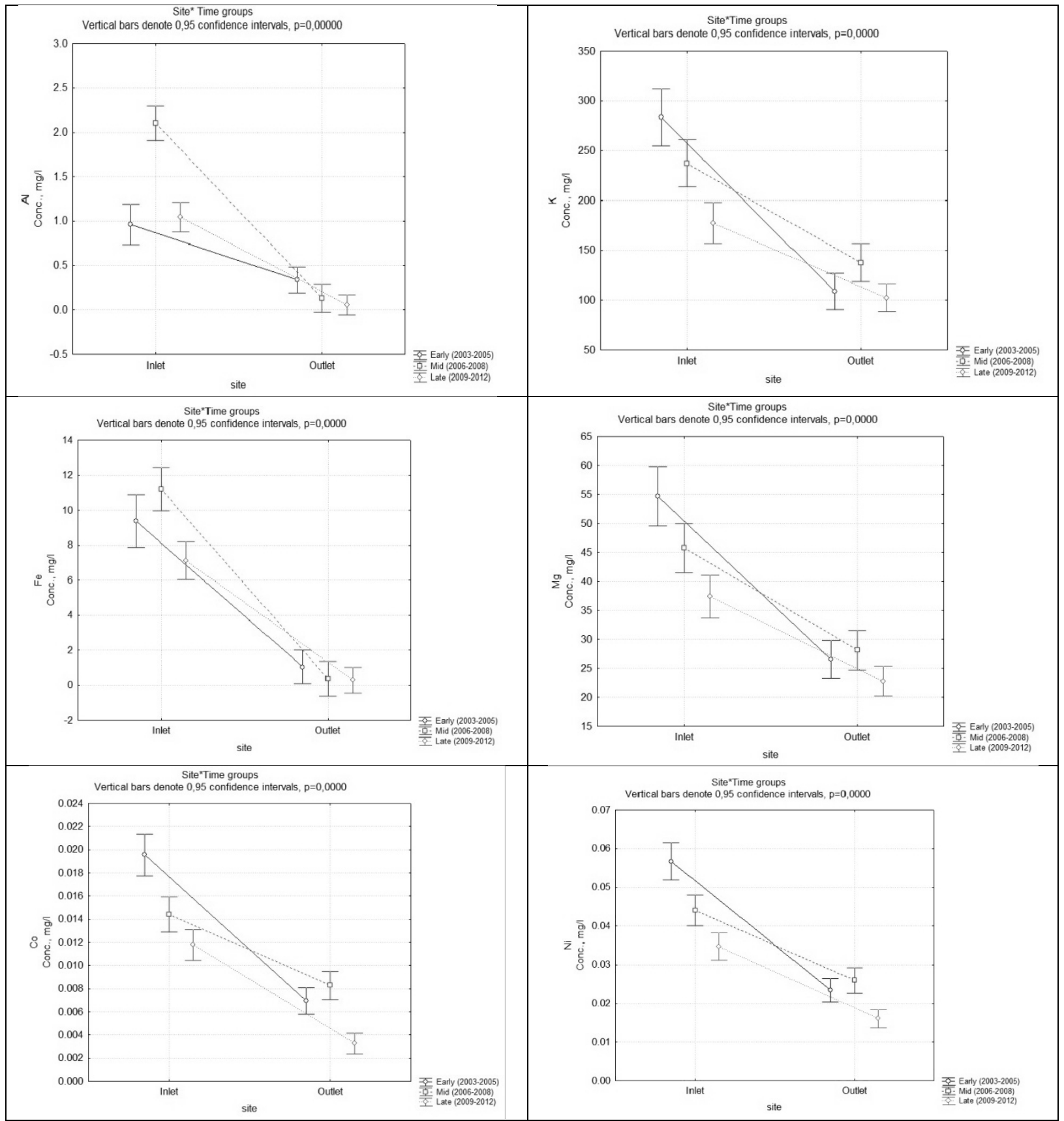

Figure 3 Metal and metalloid concentrations at two different sites (inlet and outlet) during different time groups. Al, Fe and Co belong to the elements of GROUP 1 in

Figure 1 and the elements $\mathrm{K}, \mathrm{Mg}$ and Ni belong to the elements of GROUP 2 presented in Figure 2. K and Mg are metals that occur in high concentration Co and Ni are metals with low concentration. 
The overall trend analysis has shown that the concentrations in the outlet maintain at the same level disregarding the variations in the inlet. Even though the heavy metals and metalloids are not the major environmental concern in the landfill leachate [1] and the Atleverket wetland was not specially designed for removal those pollutants it is interesting to notice that wetland sequestrates these elements to a great extent. The evidence for this phenomenon is high percentage of removal rates for almost all elements. Analytes' concentrations were significantly lower in the outlet compared to the inlet.

Removal rates were calculated using concentrations and mass in the inlet and outlet. The results have shown high retention for 11 out of 17 elements. Among them were lead (95\%), vanadium (93\%), and zinc (92\%). These elements tend to have the highest retention. However, for these compounds loading concentrations were very low and the measured concentrations in the outlet were very often below the detection limit. Therefore, for the computations in the current study, half of the detection limits were used for concentrations below the detection limit. Due to this fact it can be concluded that the removal estimation of these metals is hypothetical. Hence, the highest removal rates were achieved for Fe (93\%) followed by Mn (88\%). Also, a large portion of $\mathrm{Al}$ (87\%), As (85\%), Ba (84\%) and $\mathrm{Cr}(83 \%)$ were retained in the constructed wetland system. The coefficient of variation (CV) in the outlet for $\mathrm{Fe}, \mathrm{Mn}, \mathrm{Al}$ and $\mathrm{Zn}$ was above $100 \%$. This indicates that the elements have high variability in mean values in the effluent. Also, it can be concluded that these pollutants behave in similar way. The lowest retention rate appeared for Mg (34\%) next comes S (40\%), $\mathrm{K}(41 \%), \mathrm{B}(42 \%)$ and $\mathrm{Ni}(45 \%)$. For all the others elements the removal efficiency was above $50 \%$.

Grouping analysis indicated that the loading concentration in the influent for the elements such as $\mathrm{B}, \mathrm{Ca}, \mathrm{Ni}, \mathrm{K}, \mathrm{Mg}, \mathrm{Cr}$ and Co gradually decreased in every next time group and as a result, declined by the end of the period under review. While for the other compounds like $\mathrm{Al}$, $\mathrm{Fe}, \mathrm{Cu}, \mathrm{Mn}, \mathrm{Pb}, \mathrm{Zn}, \mathrm{Ba}$ and As the incoming concentrations increased during the 2005-2008 (mid stage) and declined in the last years 2009-2012 (late stage). In contrast, the concentration of $S$ at the inlet increased with time.

\subsection{Comparison with maximum permissible standards}

There are no maximum permissible concentrations (MPC) established for metals, metalloids and sulphur in freshwater in Sweden using risk assessment methodology. However, it was interesting to compare the obtained results with basic environmental quality standards for freshwater as the effluent is discharged onto the nearby river. The Dutch limits were chosen as a benchmark. [17] presents in their study MPCs in the environment which are used by the Dutch government for deriving environmental quality standards. The MPCs were compared to the mean and maximum concentrations in the effluent of Atleverket CW. However, determined MPCs was only available for 9 out of 17 analysed elements. These elements were As, Ba, Cr, Co, Cu, Pb, Ni, V, Zn. The results are presented in Table 2 and they demonstrate that for some elements these numbers exceeded both mean and max concentrations in the outlet, these elements are $\mathrm{Co}, \mathrm{Cu}, \mathrm{Ni}$ and $\mathrm{Zn}$. However, it should be noted that the concentrations for $\mathrm{Zn}$ were below the detection limits in the last two years, 2011 and 2012 of the study. For Cr maximum concentration in the outlet was higher than the one suggested limit by Dutch study while the mean value was below this number. Moreover, it is important to take into account the background concentrations of metals, metalloids and sulphur may vary in different geographical areas depending upon for example bedrock and adaptations of the ecological communities. 
Some studies explain the occurrence of a background concentration. It may happen when the wetland is large compared to loaded contaminated water what leads to the outflowing concentration displayed as a plateau where no further reduction has place. The reasons for this may be that some contaminants are resistant to accumulation in the wetland or that phytoplankton can contain some particles which can be also released into the water. Different natural processes occurring in the wetland can contribute to the pollution of the wetland and cause the occurrence of the background concentration in it [18], [19].

Table 2 Comparison of the metals, metalloids and sulphur concentrations at the outlet of Atleverket $C W$ with Dutch maximum permissible concentrations

\begin{tabular}{|c|c|c|c|c|}
\hline \multirow{2}{*}{ Element } & \multicolumn{3}{|c|}{ Outlet $(n=144)$} & \multirow{2}{*}{$\begin{array}{c}\mathrm{MPC}^{* *}, \\
\mathrm{mg} / \mathbf{l}\end{array}$} \\
\hline & Mean \pm SD, mg/l & Range (min-max), mg/l & $\mathrm{CV}, \%$ & \\
\hline Al & $0.158 \pm 0.195$ & $0.005-0.870$ & 123.9 & - \\
\hline As & $0.002 \pm 0.001$ & $0.0002-0.004$ & 53.4 & 0.025 \\
\hline $\mathbf{B a}$ & $0.031 \pm 0.017$ & $0.005-0.075$ & 56.1 & 0.22 \\
\hline B & $0.881 \pm 0.344$ & $0.150-1.80$ & 39.0 & - \\
\hline Ca & $52.773 \pm 16.806$ & $17.0-110.0$ & 31.8 & - \\
\hline Co & $0.006 \pm 0.004$ & $0.0014-0.018$ & 63.8 & 0.0028 \\
\hline $\mathrm{Cr}$ & $0.007 \pm 0.005$ & $0.0019-0.020$ & 65.7 & 0.0087 \\
\hline $\mathbf{C u}$ & $0.006 \pm 0.003$ & $0.00005-0.016$ & 49.3 & 0.0015 \\
\hline Fe & $0.518 \pm 0.579$ & $0.071-3.90$ & 111.8 & - \\
\hline $\mathbf{K}$ & $113.960 \pm 47.927$ & $9.20-250.0$ & 42.1 & - \\
\hline Mg & $25.327 \pm 8.484$ & $7.40-54.0$ & 33.5 & - \\
\hline Mn & $0.236 \pm 0.303$ & $0.018-1.80$ & 128.1 & - \\
\hline $\mathbf{N i}$ & $0.021 \pm 0.009$ & $0.0048-0.049$ & 44.6 & 0.0051 \\
\hline $\mathbf{P b}$ & $0.0004 \pm 0.00$ & $0.00025-0.002$ & 72.5 & 0.011 \\
\hline $\mathrm{S}$ & $22.717 \pm 8.642$ & $5.0-48.0$ & 38.0 & - \\
\hline $\mathbf{V}$ & $0.001 \pm 0.001$ & $0.000025-0.003$ & 75.3 & 0.0043 \\
\hline Zn & $0.014 \pm 0.017$ & $0.00025-0.150$ & 121.9 & 0.0094 \\
\hline
\end{tabular}

**MPC - maximum permissible concentrations (mg/l) for fresh water in the Netherlands, obtained from [17]

\subsection{Analysis of the high removal of metals and metalloids in the Atleverket CW}

There are many potential major removal mechanisms for metal and metalloids in a wetland [15]. A previous study, using data from 2003-2006 of the wetland, has shown that many of them are removed to a large extent already in the first part of the wetland system where sediment traps and a large pond treating $1 / 3$ of the wetland volume is located[13]. Concomitantly a large part of the total solids (TS) is reduced. In this part of the wetland the largest concentration of metals in the sediment has also been measured [14]. Sulphur may also serve an essential role in formation and storage of metal sulphides.

In case of iron, which is usually one of the target elements for removal from the landfill leachates, the great retention may be expected. In a surface flow constructed wetlands are usually a good tool and more effective than subsurface CW because of aerobic conditions which improve iron precipitation. The studies published earlier, show similar results with large iron reduction in constructed wetlands for LL treatment [12], [20]-[22]. While manganese is an essential element for plants vital functioning, in high concentrations it may 
be toxic to some organisms. Previous studies have stated that manganese has low removal rate as it goes through CW and [15], [23], [24] mention 54\% as average reduction rate in FWS wetlands. However, in this study Mn was retained to a large extent equal to 88\%. Aluminium is toxic to many species of algae while wetland invertebrates and macrophytes are more resistant to high $\mathrm{Al}$ concentrations. Al can form insoluble compounds which lead to oxides and hydroxides formation. Sediments are usually rich in Al. The aluminium sludge may be used for phosphorous removal [25], [26]. The Atleverket CW retains this element to a large extent, 87\%. Other sources also give large numbers of removal, over 90\% [15], [22], [23]. Cr removal in this study is $83 \%$, which is comparable with the results found in studies made by [20] and [21]. The reduction of copper was 77\% and [9], [22], [27] stated similar results in their studies. CW systems are usually not very effective for such metals as Ni [9], [22], [27]. $\mathrm{Ni}$ can be toxic in high concentrations. Plants have the potential to accumulate $\mathrm{Ni}$ in their tissues with high values in their roots. Sediments can also contain large amount of Ni. However, usually this capacity is not utilized due to low loading to the wetland. Ni very often co-precipitates with iron and manganese hydroxides and oxihydroxides [15], [22]. In Atleverket CW the removal was $45 \%$. Diverse information was found about retention of lead. [15] states that $\mathrm{CWs}$ remove $\mathrm{Pb}$ from wastewaters by accumulating it in sediment. However, it will not work effectively if the influent concentration is the same or less than background concentration. In the present paper the concentration in the outflow was often below the detection limit. This means that high removal efficiency with 95\% which the results showed is uncertain. Usually calcium, potassium and magnesium are not a threat to the environment even if they present in surface water in high concentrations.

\section{CONCLUSIONS}

The results from this study indicated that constructed wetland could be a useful tool for the removal of various metals and metalloids even though these elements are not the major targets. However, at the same time it seems that some elements, such as magnesium, boron, sulphur and nickel, are not retained very efficiently (the removal efficiency is less than $50 \%$ ). Some metals ( $\mathrm{Pb}, \mathrm{V}, \mathrm{Ba}, \mathrm{Zn})$ showed outlet concentrations below the detection limits, but low concentrations do not eliminate environmental threats, as many compounds can be assumed to be hazardous even in small amounts and negative effects are often caused by multiple and synergistic effects (Öman and Junestedt, 2008). Also, pre-treatment of the landfill leachates in the aerated lagoon is a good decision for increasing retention of some elements like the oxide formers Fe and Mn.

The study showed that Atleverket constructed wetland is an effective sink for metals and metalloids and it continues to show good removal performance for the elements measured in landfill leachates during a decade of operation.

\section{ACKNOWLEDGEMENTS}

We would like to thank Tekniska verken, Örebro for making the data available to us and for hospitality, information and many fruitful discussions during the years with Magnus Fridolfsson, Karin Karlsson and Mattias Persson. We are also grateful to Karl-Otto Waara for critical reading of the manuscript. Tatsiana Bandaruk also sends a special heartfelt gratitude to the Swedish Institute who made her stay in Sweden and this work possible. 


\section{REFERENCES}

[1] P. Kjeldsen, M. A. Barlaz, A. P. Rooker, A. Baun, A. Ledin, and T. H. Christensen, "Present and Long-Term Composition of MSW Landfill Leachate: A Review," Crit. Rev. Environ. Sci. Technol., vol. 32, no. 4, pp. 297-336, 2002.

[2] D. Kulikowska and E. Klimiuk, "The effect of landfill age on municipal leachate composition,” Bioresour. Technol., vol. 99, no. 13, pp. 5981-5985, Sep. 2008.

[3] S. Renou, J. G. Givaudan, S. Poulain, F. Dirassouyan, and P. Moulin, "Landfill leachate treatment: Review and opportunity,” J. Hazard. Mater., vol. 150, no. 3, pp. 468-493, Feb. 2008.

[4] C. B. Öman and C. Junestedt, "Chemical characterization of landfill leachates - 400 parameters and compounds,” Waste Manag., vol. 28, no. 10, pp. 1876-1891, 2008.

[5] J. Vymazal, “The use constructed wetlands with horizontal sub-surface flow for various types of wastewater,” Ecol. Eng., vol. 35, no. 1, pp. 1-17, Jan. 2009.

[6] J. Wiszniowski, D. Robert, J. Surmacz-Gorska, K. Miksch, and J. V. Weber, "Landfill leachate treatment methods: A review,” Environ. Chem. Lett., vol. 4, no. 1, pp. 51-61, Apr. 2006.

[7] L. Yang and K.-Y. Tsai, "Treatment of landfill leachate with high levels of ammonia by constructed wetland systems,” J. Environ. Sci. Heal. Part, vol. 46, no. 7, pp. 736-741, 2011.

[8] A. Galletti, P. Verlicchi, and E. Ranieri, "Removal and accumulation of $\mathrm{Cu}, \mathrm{Ni}$ and $\mathrm{Zn}$ in horizontal subsurface flow constructed wetlands: Contribution of vegetation and filling medium,” Sci. Total Environ., vol. 408, no. 21, pp. 5097-5105, Oct. 2010.

[9] A. S. Knox, E. A. Nelson, N. V. Halverson, and J. B. Gladden, "Long-Term Performance of a Constructed Wetland for Metal Removal,” Soil Sediment Contam. Int. J., vol. 19, no. 6, pp. 667-685, 2010.

[10] A. S. Sheoran and V. Sheoran, "Heavy metal removal mechanism of acid mine drainage in wetlands: A critical review,” Miner. Eng., vol. 19, no. 2, pp. 105-116, Feb. 2006.

[11] J. T. . Verhoeven and A. F. . Meuleman, "Wetlands for wastewater treatment: Opportunities and limitations,” Ecol. Eng., vol. 12, no. 1-2, pp. 5-12, Jan. 1999.

[12] J. Vymazal, M. Greenway, K. Tonderski, H. Brix, and Ü. Mander, "Constructed Wetlands for Wastewater Treatment," in Wetlands and Natural Resource Management, P. D. J. T. A. Verhoeven, D. B. Beltman, D. R. Bobbink, and D. D. F. Whigham, Eds. Springer Berlin Heidelberg, 2006, pp. 69-96.

[13] S. Waara, K.-O. Waara, Å. Forsberg, and M. Fridolfsson, "Perfomance of constructed wetland system for treatment of landfill leachate,” in Proceedings Waste 2008, Stratfordupon-Avon, Wawwickshire, England, 2008.

[14] E. Wojciechowska and S. Waara, "Distribution and removal efficiency of heavy metals in two constructed wetlands treating landfill leachate," Water Sci. Technol., vol. 64, no. 8, pp. 1597-1606, 2011.

[15] R. H. Kadlec and R. L. Knight, Treatment Wetlands : Theory and Implementation (2nd Edition), 2nd ed. CRC Press, 2008.

[16] J.-Y. Yu and B. Heo, "Dilution and removal of dissolved metals from acid mine drainage along Imgok Creek, Korea,” Appl. Geochem., vol. 16, no. 9-10, pp. 1041-1053, Jul. 2001.

[17] T. Crommentuijn, D. Sijm, J. de Bruijn, M. van den Hoop, K. van Leeuwen, and E. van de Plassche, "Maximum permissible and negligible concentrations for metals and metalloids in the Netherlands, taking into account background concentrations," J. Environ. Manage., vol. 60, no. 2, pp. 121-143, Oct. 2000. 
[18] R. H. Kadlec, "Comparison of free water and horizontal subsurface treatment wetlands," Ecol. Eng., vol. 35, no. 2, pp. 159-174, Feb. 2009.

[19] R. H. Kadlec, "Deterministic and stochastic aspects of constructed wetland performance and design,” Water Sci. Technol., vol. 35, no. 5, pp. 149-156, 1997.

[20] G. A. Di Luca, M. A. Maine, M. M. Mufarrege, H. R. Hadad, G. C. Sánchez, and C. A. Bonetto, "Metal retention and distribution in the sediment of a constructed wetland for industrial wastewater treatment,” Ecol. Eng., vol. 37, no. 9, pp. 1267-1275, Sep. 2011.

[21] S. Khan, I. Ahmad, M. T. Shah, S. Rehman, and A. Khaliq, "Use of constructed wetland for the removal of heavy metals from industrial wastewater," J. Environ. Manage., vol. 90, no. 11, pp. 3451-3457, Aug. 2009.

[22] L. Kröpfelová, J. Vymazal, J. Švehla, and J. Štíchová, "Removal of trace elements in three horizontal sub-surface flow constructed wetlands in the Czech Republic," Environ. Pollut., vol. 157, no. 4, pp. 1186-1194, Apr. 2009.

[23] E. Lesage, D. P. L. Rousseau, E. Meers, F. M. G. Tack, and N. De Pauw, “Accumulation of metals in a horizontal subsurface flow constructed wetland treating domestic wastewater in Flanders, Belgium,” Sci. Total Environ., vol. 380, no. 1-3, pp. 102-115, Jul. 2007.

[24] E. A. Nelson, W. L. Specht, and A. S. Knox, "Metal Removal from Water Discharges by a Constructed Treatment Wetland,” Eng. Life Sci., vol. 6, no. 1, pp. 26-30, 2006.

[25] J. T. Novak and C. M. Park, "The effect of iron and aluminium for phosphorus removal on anaerobic digestion and organic sulfur generation," Water Sci. Technol. J. Int. Assoc. Water Pollut. Res., vol. 62, no. 2, pp. 419-426, 2010.

[26] Y. Yang, D. Tomlinson, S. Kennedy, and Y. . . Zhao, "Dewatered alum sludge: a potential adsorbent for phosphorus removal,” Water Sci. Technol., vol. 54, no. 5, p. 207, Sep. 2006.

[27] J. Vymazal, "Horizontal sub-surface flow and hybrid constructed wetlands systems for wastewater treatment,” Ecol. Eng., vol. 25, no. 5, pp. 478-490, Dec. 2005. 